\title{
THE MIOCENE/OLIGOCENE BOUNDARY IN THE CARIBBEAN REGION
}

Sir,-The contribution by Dr. H. G. Kugler (Geol. Mag., xci, 1954, $410-413)$ on the above subject is very welcome, as it summarizes much evidence bearing on the question. To the writer it seems that much of the information required has now been brought forward, either explicitly or indirectly, and it is only in the interpretation that opinions differ. Much emphasis has been placed upon the evidence of pelagic foraminifera, but world-wide correlation must be based upon the sum total of all palaeontological evidence and not upon them alone ; even so, the study of such pelagic faunas shows that their evidence really does fall closely into line with that from other sources. On this basis probably all the Cipero formation is of Lower Miocene age.

The writer does not consider it prudent "to expect the presence of sediments of the entire Oligocene time where carbonate deposits were laid down from Upper Eocene times into the Oligocene ". The amount of Oligocene present must surely be deduced from an impartial consideration of all palaeontological evidence $a b$ initio. In a region such as the Caribbean, there is no reason why Lower and Upper Oligocene should not be missing in many areas, as is, indeed, the case in a number of other parts of the world, where only the Rupelian (Middle Oligocene) is developed.

Finally, I would question whether the definition of the top of the Oligocene merits the attention of the International Geological Congress, except, perhaps, to confirm that it occurs between the Chattian and Aquitanian.

The British Petroleum Co., LtD.,

F. E. EAmes.

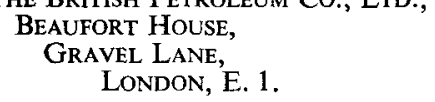

3rd January, 1955.

\section{IRANOLEESIA, NEW TRILOBITE NAME}

SIR,-It has been pointed out to me by Dr. C. J. Stubblefield that the generic name Irania, under which I described a trilobite from Persia, Pal. Indica, 1937, xxii, Mem. 5, p. 12, is preoccupied by Irania F. de Filippi in Arch. Anat. Fisiol., 1863, 2, fasc. 2, 380, Modena. I therefore suggest the genus be renamed Iranoleesia after Dr. G. M. Lees.

\section{SedGWick Museum,} CAMBRIDGE.

3rd January, 1955. 